\title{
On the Biology of Siganus rivulatus Inhabits Bitter Lakes in Egypt
}

\section{El-Drawany*}

Department of Zoology, Faculty of Science, Zagazig University, Egypt

\begin{abstract}
The present work was carried out to study the age, growth, length-weight relationships, spawning season, length at first sexual maturity and mortality of the commercial Rabbit fish, Siganus rivulatus, inhabits Bitter Lakes in Egypt. Fish samples which were collected during the period from January to December 2011 were selected to represent all fish size categories in the catch. Each fish specimen was measured, weighted and then dissected to detect the maturity stage of the gonads. The annual rates of total, natural and fishing mortality were calculated as $0.8840,0.2214$ and $0.6626^{y r-1}$ respectively. Current exploitation rate 'E' was estimated at 0.75 . The length-weight relationships for males and females were estimated, respectively as:

$W=0.01042 \times L^{3.0101}$ and $W=0.00952 \times L^{3.042}$.

The age data derived from the otolith readings were used to estimate the growth parameters of the von Bertalanffy growth equation. The estimated parameters were: $L_{\infty}=35.5 \mathrm{~cm}, K=0.0849$ and $t=-0.843$ for females, otherwise they were: $L_{\infty}=36.5 \mathrm{~cm}, K=0.0786$ and to $=-1.00382$ for males. It was found that, both males and females matured at $a$ total length of about $15.4 \mathrm{~cm}$. The natural spawning period of this fish species is in the summer, from May to July.
\end{abstract}

Keywords: Environment; Fishes; Phytoplankton; Fishery production

\section{Introduction}

The Siganidae form a small family of herbivorous, widely distributed fishes in the Indo-West Pacific Ocean [1]. They are of economic importance for the fishery production in several countries in the Indo Pacific and Middle East regions. S. rivulatus has established large populations in its new environment and can be considered as one of the most successful Lessepsian fish [2-4]. It was found in several different overgrown habitats (rocks with algae, sand with algae, and grass with algae) it is considered to be strictly herbivorous $[5,6]$. Siganus rivulatus are mainly found in shallow water, usually less than 15 meters. This shallow depth should be predictable for species that is almost entirely herbivorous where algae are the more widespread at these depths. The fishes begin their life as a phytoplankton feeder on many small diatoms, then ingest zooplankton consisting of copepods species [7]. The type and amount of food influence significant the body composition and its nutritional value [8]. Family Siganidae have a single row of flattened close-set teeth for rasping at meatier seaweeds. The mouth is specially designed to aid in the removal of algae from in between rock crevices, or coral branches. The upper jaw is fixed, with only the tip of the mouth being able to move up or down creates a nibbling action. Five species of Siganids are known in the northwestern area of Red Sea [9]. Two of which have immigrated through the Suez Canal and now are established itself successfully in the eastern Mediterranean up to the Aegean sea and along the coast of Egypt and Libya up to Tunisia in the southern Mediterranean [10]. The first species is dominant in the Egyptian waters of Mediterranean, in the coastal area off Alexandria [11] especially in Abu-Qir Bay [12]. Information about Siganus rivulatus age and pertinent growth rate were studied in both the Red Sea [9-15] and in the Mediterranean [16-19]. An existing data mainly concern the reproductive biology and rearing experiments [20-24] have been reported. The Rabbit fish Siganus rivulatus Forsskal [25] hold particular promise for marine aquaculture development by virtue of their herbivorous/omnivorous feeding habits and consequent ability to feed low on the aquatic food chain [26], their high tolerance to environmental factors, rough handling and crowding [27] fast growth and possibility to obtain their seeds from the wild or by artificial propagation [28]. Therefore, the aim of the present study is concerned with the updating biological aspects of Siganus rivulatus which is one of the dominant fish species occurring in the artisanal fishery of the studying area. Such information could be employed for best planning of fishing and culturing this fish in the Egyptian waters moreover managing its stock in the area of study.

\section{Materials and Methods}

As regards to 420 specimens of Rabbit fish, Siganus rivulatus, were collected monthly around 2011, from the landing site at Bitter lakes. Fishes were put immediately in crushed ice and transported to the laboratory, where they were subjected investigation. Date of capture, total fish length $(\mathrm{mm})$ and total fish weight $(0.1 \mathrm{~g})$ were recorded for each fresh specimen. Fishes were dissected to define their sex and gonad maturity stages. Gutted fish were weighed to the nearest $0.1 \mathrm{~g}$ and gonads were weighed to the nearest $0.001 \mathrm{~g}$. Both otoliths (Sagittae) of each fish specimens were removed, cleaned in ethanol and stored for age determination after drying. The otoliths then after were treated with xylene and moistened with chamomile oil [19] to be clearly visible under reflected light microscope in order to read the annual rings. Counts of rings and measurements were always performed in the same direction, from the nucleus to the edge of the otolith. Backcalculation of total length, were obtained by Lee's equation. The growth parameters $\mathrm{L}_{\infty}, \mathrm{k}$ and $\mathrm{t}_{0}$ of Siganus rivulatus were estimated by means of von Bertalanffy plot (Sparre and Venema [29] and application of von Bertalanffy equation von Bertalanffy [30].

$$
\mathrm{L}_{\mathrm{t}}=\mathrm{L}_{\infty}\left(1-\mathrm{e}^{-\mathrm{k}(\mathrm{t}-\mathrm{to})}\right)
$$

Where $\mathrm{L}_{t}$ is the total length at time $t ; k$ is a growth constant; $\mathrm{L}_{\infty}$

*Corresponding author: El-Drawany, Department of Zoology, Faculty of Science, Zagazig University, Egypt, E-mail: samy_drawany@yahoo.com

Received March 14, 2015; Accepted March 31, 2015; Published April 25, 2015

Citation: El-Drawany (2015) On the Biology of Siganus rivulatus Inhabits Bitter Lakes in Egypt. J Aquac Res Development 6: 342. doi:10.4172/2155-9546.1000342

Copyright: (C 2015 El-Drawany. This is an open-access article distributed under the terms of the Creative Commons Attribution License, which permits unrestricted use, distribution, and reproduction in any medium, provided the original author and source are credited. 
Citation: El-Drawany (2015) On the Biology of Siganus rivulatus Inhabits Bitter Lakes in Egypt. J Aquac Res Development 6: 342. doi:10.4172/21559546.1000342

Page 2 of 6

is the asymptotic length; and $t \theta$ describes the theoretical age where $\mathrm{L}_{\mathrm{t}}$ is zero [31]. The length weight relationships were estimated from the allometric equation, $\mathrm{W}=\mathrm{a} \mathrm{L}^{\mathrm{b}}$ Ricker [32] where $\mathrm{W}$ is total body weight $(\mathrm{g}), \mathrm{L}$ the total length $(\mathrm{cm})$, $\mathrm{a}$ and $\mathrm{b}$ are the coefficients of the functional regression between (W) and (L) and they were obtained using the Newton algorithm from the Microsoft Excel Solver routine.

The spawning season was determined by the curvilinear average values of monthly Gonadosomatic index (GSI) for both males and females where:

GSI $=100$ [gonads weight $(\mathrm{g}) /$ gutted weight $(\mathrm{g})]$

Total mortality rate $(Z)$ was estimated based on the length at first capture methods evaluated by Beverton and Holt 1957 [33]

$\mathrm{Z}=\mathrm{K}\left(\mathrm{L}_{\infty}-\mathrm{Lm} / \mathrm{Lm}-\mathrm{Lc}\right)$

Where:

$\mathrm{Lm}=$ the average total length of the entire catch.

$\mathrm{Lc}=$ the length at which $50 \%$ of the fish entering the gear

Natural mortality rate $(\mathrm{M})$ was estimated by using the equation derived by Ursin [34] based on the mean total length where:

$\mathrm{M}=\mathrm{W}^{-(1 / \mathrm{b})}$

$\mathrm{W}=$ mean total length.

$\mathrm{b}=$ constant of length weight relationship.

Fishing mortality rates (F) were calculated as the difference between $\mathrm{Z}$ and $\mathrm{M}$ where $\mathrm{Z}=\mathrm{F}+\mathrm{M}$.

The annual exploitation rate (E) was obtained according Sparre et al. where: $\mathrm{E}=\mathrm{F} / \mathrm{Z}$

The total mortality coefficient "Z" was estimated using the method of Pauly [35].

\section{Results}

\section{Total length frequency distribution}

The total length of all individuals $(n=420)$ collected in the present study ranged from 9 to $28.7 \mathrm{~cm}$, and the most frequent length was 18 $\mathrm{cm}$ as illustrated in Figure 1 and Table 1.

\section{The age composition and growth}

The age distribution of samples ranged from I to VI years for $S$. rivulatus, based on the results of otolith reading (Figure 2). The age group III was dominant (27.6\%) for male followed by age groups II

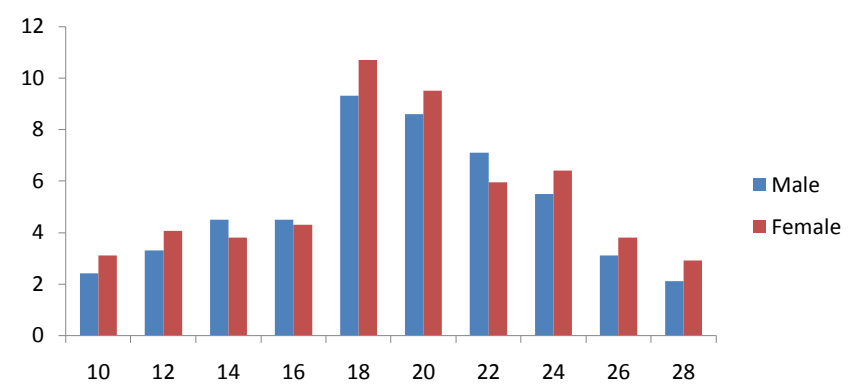

Figure 1: Length frequency distribution of male and female of Siganus rivulatus.

\begin{tabular}{|c|c|c|c|c|c|c|c|c|}
\hline \multirow[t]{2}{*}{ Age group } & \multirow{2}{*}{$\begin{array}{c}\text { Mean } \\
\text { number }\end{array}$} & \multirow{2}{*}{$\begin{array}{c}\text { Observed } \\
\text { Length } \\
(\mathrm{mm})\end{array}$} & \multicolumn{6}{|c|}{ Back calculated lengths in $\mathrm{mm}$} \\
\hline & & & 1 & 2 & 3 & 4 & 5 & 6 \\
\hline $\mathbf{I}$ & 34 & 11.0 & 10.46 & & & & & \\
\hline II & 41 & 15.5 & 10.69 & 14.15 & & & & \\
\hline III & 61 & 18.9 & 11.50 & 15.20 & 17.68 & & & \\
\hline I V & 36 & 21.7 & 11.35 & 15.37 & 16.98 & 20.19 & & \\
\hline $\mathbf{V}$ & 33 & 23.9 & 10.81 & 15.85 & 18.81 & 20.90 & 23.44 & \\
\hline VI & 12 & 26.4 & 10.75 & 15.34 & 19.52 & 22.02 & 23.69 & 25.36 \\
\hline Average total & 217 & & 10.92 & 15.18 & 18.95 & 21.44 & 23.57 & 25.36 \\
\hline $\begin{array}{l}\text { Increment of } \\
\text { length }\end{array}$ & & & 10.92 & 4.26 & 3.77 & 2.49 & 2.13 & 1.79 \\
\hline $\begin{array}{l}\% \text { of annual } \\
\text { Increment }\end{array}$ & & & 43.1 & 16.88 & 14.87 & 9.82 & 8.40 & 7.06 \\
\hline
\end{tabular}

Table 1: Average back-calculated lengths $(\mathrm{cm})$ of male Siganus rivulatus from the Bitter lakes, Egypt.

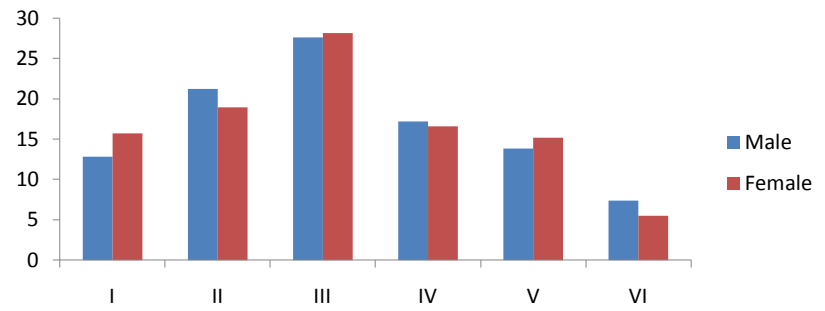

Figure 2: Relative age frequency of males and females of Siganus rivulatus.

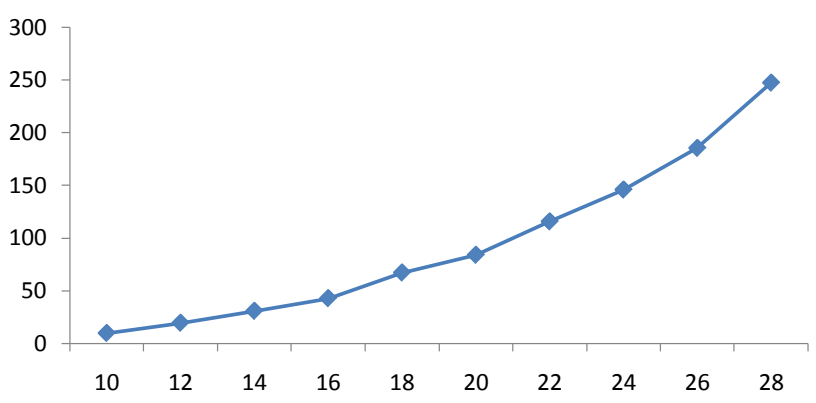

Figure 3: Length weight relationship of female Siganus rivulatus.

(21.2\%), IV (17.2\%), V (13.8), I (12.8) and VI (7.4\%), While the age group III was dominant (28.1\%) for female followed by age groups II (18.9\%), IV (16.6\%), I (15.7\%), V (15.2\%) and VI (5.5\%). The growth of the studied fish was described by the von Bertalanffy model based on the back-calculated length at age data (Figure 3 ). The estimated growth functions were:

$$
\begin{aligned}
& \mathrm{L}_{\mathrm{t}}=36.5 \mathrm{~cm}\left(1-\mathrm{e}^{-0.0786(\mathrm{t}+1.0038)}\right) \text { for males and } \\
& \mathrm{L}_{\mathrm{t}}=35.5 \mathrm{~cm}\left(1-\mathrm{e}^{-0.0849(\mathrm{t}+0.8430)}\right) \text { for females }
\end{aligned}
$$

Growth in both sexes is almost similar ( $\mathrm{K}=0.0786$ for males and $\mathrm{K}=0.0849$ for females). However, the maximum theoretical length were $36.5 \mathrm{~cm}$ and $35.5 \mathrm{~cm}$ for males and females, respectively.

\section{Growth in length}

The otolith radius-total length relationship of males and females are described by the following equations:

$$
\mathrm{L}=5.3227+4.0465 \mathrm{~S} \text { for males }\left(\mathrm{r}^{2}=0.998\right) \text { and }
$$


Citation: El-Drawany (2015) On the Biology of Siganus rivulatus Inhabits Bitter Lakes in Egypt. J Aquac Res Development 6: 342. doi:10.4172/21559546.1000342

\section{$\mathrm{L}=4.8465+4.01173 \mathrm{~S}$ for females $\left(\mathrm{r}^{2}=0.995\right)$}

Where: $\mathrm{L}$ is the total length in centimeters, $\mathrm{S}$ is the otolith radius in millimeters and $\mathrm{r}$ is the correlation coefficient.

\section{Back-calculations}

The following formula was derived to obtain the back-calculated total length at the end of each year of life for males and females respectively.

$\mathrm{Ln}=(\mathrm{L}-5.3227) \mathrm{Sn} / \mathrm{S}+5.3227$

$$
\mathrm{Ln}=(\mathrm{L}-4.8465) \mathrm{Sn} / \mathrm{S}+4.8465
$$

Where: $\mathrm{Ln}$ is the length at the end of $\mathrm{n}^{\text {th }}$ year, $\mathrm{Sn}$ is the radius of the otolith to $\mathrm{n}^{\text {th }}$ annulus, $\mathrm{S}$ is the total radius of the otolith and $\mathrm{L}$ is the total length at capture. From the data given in Tables 1 and 2, it is obvious that, $\mathrm{S}$. rivulatus attains its highest growth rate in terms of length during the first year of life, after which a gradual decrease in growth increments was noticed with further increase in age.

\section{Length-weight relationship}

The total length of S. rivulatus varied from 9.0 to $28.5 \mathrm{~cm}$ and 9.0 to $28.9 \mathrm{~cm}$ for males and females respectively, while the total weights ranged between 10.83 to $246.7 \mathrm{~g}$. for males and 10.68 to $248.3 \mathrm{~g}$ for females. The equations were extracted for describing the relationship between weight and length for both sexes as follows:

$\mathrm{W}=0.00952 * \mathrm{~L}^{3.042}\left(\mathrm{r}^{2}=0.98\right) \quad$ or $\log \mathrm{W}=-2.02136+3.0424 \log \mathrm{L}$ for female and $\mathrm{W}=0.01042 * \mathrm{~L}^{3.010}\left(\mathrm{r}^{2}=0.98\right)$ or $\log \mathrm{W}=-1.9821+3.010$ Log L for female

Where:

$\mathrm{W}$ is the total weight $(\mathrm{gm})$

$\mathrm{L}$ is the total length $(\mathrm{cm})$

$\mathrm{R}$ is the correlation coefficient.

The high values of $\mathrm{r}^{2}$ indicate a good measure for the strength of these equations and closeness of observed and calculated values of fish weight. The length and weight measurements of the analyzed specimens used to describe the length-weight relationship are given in Figures 3 and 4 .

\section{Condition factor}

The present results of condition factor revealed that the $(\mathrm{Kn})$ values fluctuated between 0.98-1.04 with an average of 0.999 for males and

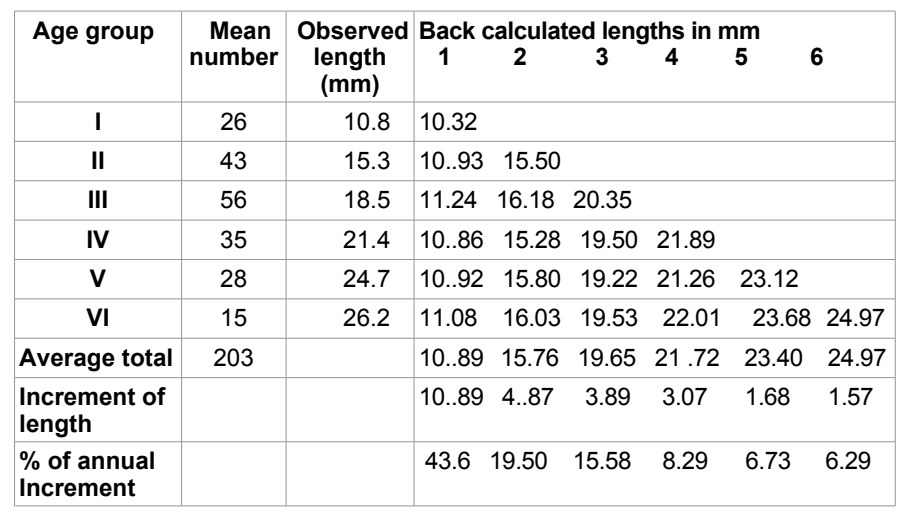

Table 2: Average back-calculated lengths $(\mathrm{cm})$ of female Siganus rivulatus from the Bitter lakes, Egypt.

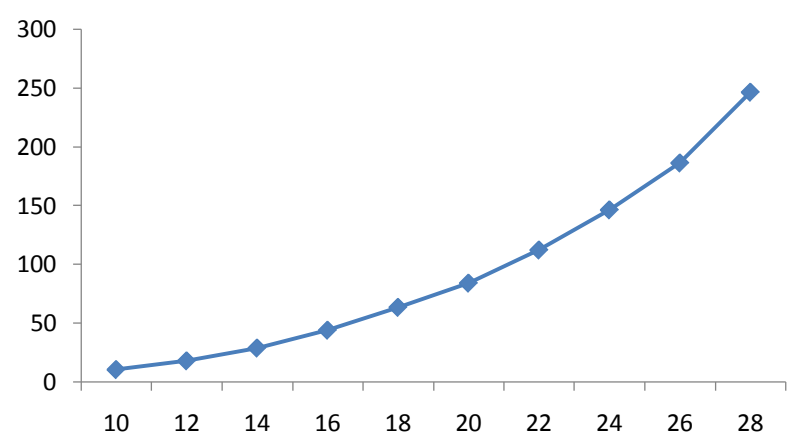

Figure 4: Length weight relationship of male Siganus rivulatus.

\begin{tabular}{|c|c|c|c|c|c|c|c|}
\hline \multirow[t]{2}{*}{ Age group } & \multirow{2}{*}{$\begin{array}{c}\text { Mean } \\
\text { number }\end{array}$} & \multicolumn{6}{|c|}{ Back calculated weights in (g) } \\
\hline & & & 2 & 3 & & 5 & 6 \\
\hline $\mathbf{I}$ & 34 & 11.55 & & & & & \\
\hline II & 41 & 13.76 & 39.82 & & & & \\
\hline III & 61 & 14.98 & 45.38 & 91.16 & & & \\
\hline IV & 36 & 13.49 & 38.13 & 80.06 & 113.82 & & \\
\hline $\mathbf{v}$ & 33 & 13.72 & 42.21 & 76.62 & 104.14 & 134.41 & \\
\hline VI & 12 & 14.34 & 44.11 & 80.44 & 115.73 & 144.56 & 168.44 \\
\hline Average total & 217 & 13.64 & 41.93 & 82.07 & 111.23 & 139.49 & 168.44 \\
\hline Increment of weight & & 13.64 & 28.29 & 40.14 & 29.16 & 28.26 & 28.95 \\
\hline
\end{tabular}

Table 3: Calculated weights $(\mathrm{g})$ of male Siganus rivulatus from the Bitter lakes, Egypt.

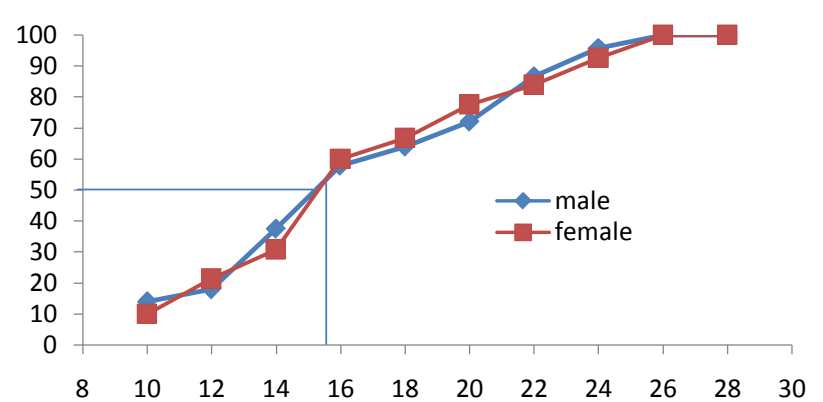

Figure 5: Length at first sexual maturity of both sexes of Siganus rivulatus.

between 0.92-1.07 with an average of 1.00 for females (Table 3).

\section{Length at first maturity}

To determine the length at first maturity, males and females were grouped into $10 \mathrm{~mm}$ size groups and the percentage occurrence of fish at the different maturity stages in each size group was calculated. Examination of the male and female maturity stages indicated that males and females of $S$. rivulatus matured at about $15.5 \mathrm{~cm}$ total length (2 year old) (Figure 5).

\section{Gonadosomatic Index (GSI)}

The monthly changes in GSI values of individuals of both sexes are given in Figure 6. It was observed that the GSI values of males and females were low during February, March, and April 2011. Index values began to increase after April to reached maximum values in July, and then began to decrease indicating that its breeding season is in July. 
Citation: El-Drawany (2015) On the Biology of Siganus rivulatus Inhabits Bitter Lakes in Egypt. J Aquac Res Development 6: 342. doi:10.4172/21559546.1000342

\section{Growth in weight}

The calculated weights at the end of each year of life of S. rivulatus were estimated by applying the corresponding length-weight equation to the back calculated lengths. The resulting values are given in Tables 3 and 4 . The obtained results for males and females indicated that the growth rate in weight was slow during the first year of life. Then the annual growth increment in weight increased with further increase in age until it reached its maximum value at the end of the third year of life, after which a decrease in the growth increment was observed.

\begin{tabular}{|c|c|c|c|c|c|c|c|}
\hline Age group & $\begin{array}{c}\text { Mean } \\
\text { number }\end{array}$ & $\begin{array}{l}\text { Back } \\
1\end{array}$ & $\begin{array}{c}\text { calcula } \\
2\end{array}$ & $\begin{array}{l}\text { ated weig } \\
3\end{array}$ & $\underset{4}{\text { ghts in (g) }}$ & 5 & 6 \\
\hline I & & 12.21 & & & & & \\
\hline II & 41 & 13.04 & 30.32 & & & & \\
\hline III & 61 & 16.24 & 37.61 & 81.83 & & & \\
\hline IV & 36 & 15.61 & 38.89 & 72.91 & 105.16 & & \\
\hline $\mathbf{v}$ & 33 & 13.48 & 42.66 & 83.47 & 112.89 & 138.51 & \\
\hline VI & 12 & 13.26 & 38.66 & 77.89 & 114.76 & 143.00 & 169.37 \\
\hline Average total & 217 & 13.97 & 37.63 & 79.03 & 110.94 & 140.76 & 169.37 \\
\hline Increment of weight & & 13.97 & 23.66 & 41.40 & 31.91 & 29.82 & 28.6 \\
\hline
\end{tabular}

Table 4: Calculated weights of female Siganus rivulatus from the Bitter lakes, Egypt.

\section{Sex ratio}

As presented in Table 6, the percentage of females to males (sex ratio) of Siganus rivulatus, in Bitter lakes is fluctuated around the year. It was obvious that sex-ratio deviate significantly from 1:1 among the size classes. However, the overall sex ratio (Males: Females) of this species during the year was $1: 1.079$ and did not differ significantly from 1:1. It ranged between 48.4 in June as a minimum value to 55.8 in December, maximum one. However, the number of both sexes is equal with percentage $50.0 \%$ in May. But in July (spawning period) the males somewhat predominated females (percentage of sex ratio is $48.5 \%$ ).

\section{Mortality rates}

By using the cumulative curve of S. rivulatus (Figure 7) illustrating length at first capture at $50 \%$ and applying the method of Sparre et al. the total mortality coefficient $(\mathrm{Z})$ was estimated. This coefficient was found to be 0.8840 year-1. But the Natural mortality coefficient "M" which obtained from the mean total length was $0.2214^{\text {year }-1}$. Using the estimated $(\mathrm{M})$ and $(\mathrm{Z})$ the fishing mortality $(\mathrm{F})$ was obtained $(0.6626$ year-1), where $Z=M+F$.

\section{Exploitation rate $(\mathrm{E})$}

According to Gulland [36] who suggested that the optimum exploitation rate in an exploited stock should equal approximately 0.50 .

\begin{tabular}{|c|c|c|c|c|c|c|}
\hline Author & Location & Year & $\operatorname{sex}$ & $L \infty(\mathbf{c m})$ & K (year $\left.{ }^{-1}\right)$ & to (year) \\
\hline El-Gammal [13] & Red Sea (Egypt & 1988 & $\begin{array}{l}M \\
F\end{array}$ & $\begin{array}{l}31.5 \\
34.2\end{array}$ & $\begin{array}{l}0.501 \\
0.434\end{array}$ & $\begin{array}{c}-0.09373 \\
-0.1002\end{array}$ \\
\hline EL-Okda [23] & Red Sea (Egypt & 1991 & $\begin{array}{l}M \\
F \\
C\end{array}$ & $\begin{array}{l}30.6 \\
31.2 \\
30.9\end{array}$ & $\begin{array}{l}0.513 \\
0.499 \\
0.505\end{array}$ & $\begin{array}{l}-0.07638 \\
-0.04007 \\
-0.05562\end{array}$ \\
\hline EL-Okda [23] & Mediterranean(Egypt) & 1998 & $\mathrm{C}$ & 32.0 & 0.299 & -0.09786 \\
\hline Bilecenoglu and Kaya [18] & Med. (Turkey) & 2002 & $\begin{array}{l}\mathrm{M} \\
\mathrm{F} \\
\mathrm{C}\end{array}$ & $\begin{array}{l}21.1 \\
22.6 \\
22.3\end{array}$ & $\begin{array}{l}0.345 \\
0.267 \\
0.279\end{array}$ & $\begin{array}{l}-0.537 \\
-0.473 \\
-0.503\end{array}$ \\
\hline El-Ganainy and Ahmed [15] & Red (Egypt) & 2002 & $\mathrm{C}$ & 29.4 & 0.735 & -0.220 \\
\hline Mehanna and Abdallah [39] & Red (Egypt) & 2002 & C & 37.1 & 0.397 & -0.186 \\
\hline Bariche [43] & Mediterr. (Lebanon) & 2005 & C & 31.9 & 0.225 & -1.307 \\
\hline Present study & Bitter Lakes Egypt & 2011 & $\begin{array}{l}\mathbf{M} \\
\mathbf{F}\end{array}$ & $\begin{array}{l}36.5 \\
35.5\end{array}$ & $\begin{array}{l}0.0786 \\
0.0849\end{array}$ & $\begin{array}{c}-1.0038 \\
-0.843\end{array}$ \\
\hline
\end{tabular}

Table 5: Von Bertalanffy parameters from the literature and the present study for male (M), female (F) and combined sex (C) of Siganus rivulatus.

\begin{tabular}{|c|c|c|c|c|c|c|}
\hline Authors & Location & year & sex & a & b & $\mathbf{r}$ \\
\hline Hashem [9] & Red Sea (Saudi Arab.) & 1983 & combined & 0.021 & 3.071 & - \\
\hline El-Gammal [13] & Red Sea (Egypt) & 1988 & $\begin{array}{l}\text { Male } \\
\text { Female }\end{array}$ & $\begin{array}{l}0.012 \\
0.011\end{array}$ & $\begin{array}{l}2.838 \\
2.841\end{array}$ & $\begin{array}{l}0.99 \\
0.99\end{array}$ \\
\hline Mohamed [17] & Mediterranean Sea (Egypt) & 1991 & $\begin{array}{c}\text { Male } \\
\text { Female } \\
\text { Combined }\end{array}$ & $\begin{array}{l}0.018 \\
0.017 \\
0.012\end{array}$ & $\begin{array}{l}2.830 \\
2.866 \\
2.934\end{array}$ & $\begin{array}{l}0.99 \\
0.99 \\
0.99\end{array}$ \\
\hline EL-Okda [23] & Mediterranean Sea (Egypt) & 1998 & Combined & 0.016 & 2.872 & - \\
\hline $\begin{array}{c}\text { Taskavak and } \\
\text { Bilecenoglu [18] }\end{array}$ & Mediterranean Sea (Turky) & 2001 & Combined & 0.047 & 3.203 & 0.98 \\
\hline Mehanna and Abdallah [39] & Mediterranean Sea (Egypt) & 2002 & Combined & 0.022 & 2.820 & 0.93 \\
\hline Bilecenoglu and Kaya [18] & Mediterranean Sea (Turky) & 2002 & $\begin{array}{c}\text { Male } \\
\text { Female } \\
\text { Combined }\end{array}$ & $\begin{array}{l}0.075 \\
0.064 \\
0.071\end{array}$ & $\begin{array}{l}3.135 \\
3.221 \\
3.179\end{array}$ & $\begin{array}{l}0.95 \\
0.95 \\
0.95\end{array}$ \\
\hline Mehanna and Abdallah [39] & Red Sea (Egypt) & 2002 & Combined & 0.012 & 3.020 & - \\
\hline Tharwat and Al-Owafeir & Red Sea (Saudi Arb.) & 2003 & Combined & 0.013 & 2.990 & 0.99 \\
\hline Bariche et al. [43] & $\begin{array}{l}\text { Mediterranean Sea } \\
\text { (Lebanon) }\end{array}$ & 2005 & $\begin{array}{c}\text { Male } \\
\text { Female } \\
\text { Combined }\end{array}$ & $\begin{array}{l}0.020 \\
0.010 \\
0.010\end{array}$ & $\begin{array}{l}3.323 \\
3.011 \\
3.037 \\
\end{array}$ & $\begin{array}{l}0.95 \\
0.96 \\
0.99\end{array}$ \\
\hline Present study & Bitter Lakes (Egypt) & 2011 & $\begin{array}{c}\text { Male } \\
\text { Female }\end{array}$ & $\begin{array}{l}0.0104 \\
0.0095\end{array}$ & $\begin{array}{l}3.010 \\
3.042\end{array}$ & $\begin{array}{l}0.98 \\
0.98\end{array}$ \\
\hline
\end{tabular}

Table 6: Estimated parameters of S. rivulatus recorded by some other authors in different regions. 


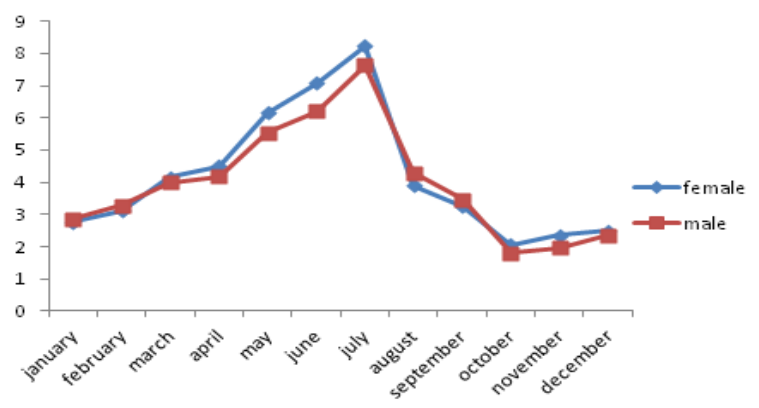

Figure 6: Monthly changes in the Gonadosomatic Indexofboth sex of S. rivulatus.

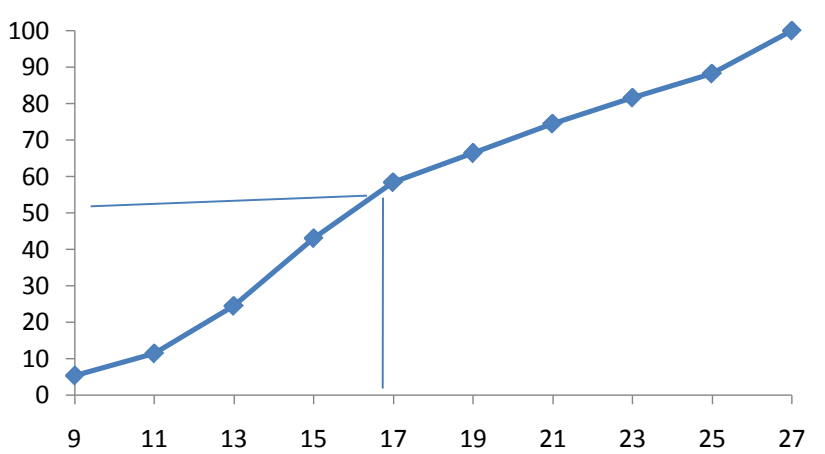

Figure 7: Cumulative curve from which length at first capture was determined.

The current exploitation rate "E" was estimated at 0.75 . Accordingly, the high value of the current exploitation rate indicates that the stock of S. rivulatus in the Red Sea is subjected to overfishing.

\section{Length at first capture (Lc)}

The length at first capture L50\% (the length at which $50 \%$ of the fish are first exposed to capture) was estimated as a component of the length converted catch curve analysis (FiSAT), was found to be $16.4 \mathrm{~cm}$ which corresponds to an age of 2.37 years.

\section{Discussion}

The most abundant size class $(18 \mathrm{~cm})$ for both sexes of $\mathrm{S}$. rivulatus, is composed of individuals that have already reproduced $(15.5 \mathrm{~cm})$. This observation is closed to that reported for the same species at Libyan coast [25]. The same authors stated that, the age is necessary to assess population dynamics and the state of exploited resources. The opaque zone on the Otoliths of $S$. rivulatus corresponds to a rapid growth but the translucent zone to a slow growth of the fish. This phenomenon is observed in a large number of fish species living in subtropical and temperate regions in tropical regions Brothers, [37] and in other Lessepsian species [38]. The maximum ages for males and females of Siganus rivulatus were observed at six years in the present study. However, Mohamed stated that, the maximal age of both males and females of Siganus rivulatus were four years in Alexandria region, while Bariche estimated it to be six years in Batrun, Lebanon. On the other hand, in Red Sea, El-Gammal estimated the maximal age to be four and five years for males and females respectively whereas Mehanna and Abdallah [39] estimated five years for combined sex for the same fish species using the same method. Otherwise, Hashem estimated six years in Mediterranean and Red Sea respectively for Siganus rivulatus using the Peterson (length frequency) method. Hussein recorded six years while Bilecenoglu and Kaya determined eight years of Mediterranean Sea for the same fish using posterior body scale reading. Also, Shiekheldin recorded six years in the Red Sea, using the same method and El-Okda determined four years as maximum age using the vertebrae. These differences between the age groups may be returned to the way of samples collection and its length range or the method used in age determination [19]. The maximum theoretical length is found to be slightly higher but in accordance with those available in the literature for S. rivulatus, except for those calculated by Mehanna and Abdallah (Table 5). The differences between parameters of the von Bertalanffy growth equation in different locations (Mediterranean and Red Sea) found in Table 5 may be resulted from different factors such as sampling, ageing method used or even geographical differences of habitats and fish condition. Von Bertalanffy parameters from the literature and the present study for male $(\mathrm{M})$, female $(\mathrm{F})$ and combined sex (C) of Siganus rivulatus (Table 6). The sex ratio of females to males for all individuals of $S$. rivulatus was about 1.079: 1. However this ratio varied in different length groups. These changes in percentage of females to males were most probably due to spawning and feeding migration [40]. The increase in ratio of females in February to April and the decrease of such ratio in September and October may be due to feeding migrations. In the other hand, the relatively equal percentage in May, June and July, which is accepted as spawning period, all population members come together and form sex ratio of about $1: 1$ (spawning migrations). The spawning season of S. rivulatus in Bitter Lakes extended from May to July (i.e. three months). These observation is closed to that reported for the same species at Turkey [41], at Israel [42] and at Lebanon [43] and slightly differed from that mentioned in the Mediterranean coast of Turkey by Torcu [44] and Yeldan and Avsar [40] from April to August and of Alexandria by Hussein from July to August as well Mohamed [17] and El-Okda [23] from May to August. In the other hand, the spawning season of Siganus rivulatus in Red Sea begins earlier than in Mediterranean as reported by Popper et al. [45] at the Gulf of Aqaba, also Hashem [9] from March to April and by Amin [20] from February to April at Jeddah region of the Red Sea. The value of total mortality obtained from the present study $(\mathrm{Z}=0.884$ year $\left.^{-1}\right)$ is agree with that reported by El-Gammal [13] in the Red Sea at Ghardaqa region where $\mathrm{Z}=0.82 \mathrm{year}^{-1}$. Nonetheless, it is lower than that estimated by Mehanna and Abdallah [39] in the Egyptian sector of the Red Sea $\left(Z=1.270^{\text {year- }-1}\right)$, and El-Ganainy and Ahmed in the eastern side of Suez Gulf $\left(Z=3.15^{\text {year- }-1}\right)$. On the other hand, the natural and fishing mortalities $\left(\mathrm{M}=0.2214\right.$ and $\left.\mathrm{F}=0.6626^{\text {year- }-1}\right)$ in the present study are lower than that obtained by El-Ganainy and Ahmed [15] in the eastern side of Suez Gulf $(\mathrm{M}=1.43$ and $\mathrm{F}=1.72)$ and nearly equal to that reported by Mehanna and Abdallah [39] ( $\mathrm{M}=0.26$ and $\left.\mathrm{F}=1.01^{\text {year-1}}\right)$. Concerning mortality estimates, comparison is so difficult due to shortage of data and the total mortality coefficient is not a species-specific parameter, but an area specific parameter.

The exploitation rate of Siganus rivulatus in the present study $(E=0.75)$ is higher than 0.50 . of Gulland suggested that as a rule of thumb a fish stock is optimally exploited at a level of fishing mortality that generates $\mathrm{E}=0.50$ where optimum fishing mortality equal the natural mortality $(\mathrm{F}=\mathrm{M})$. However, Pauly [35] proposed a lower optimum fishing mortality $(\mathrm{F}=0.40)$. Therefore, the stock of rabbit fish (Siganus rivulatus) from the Bitter lakes is being seriously over-exploited by the nylon trammel nets used, such observation noted also in Egyptian sector of the Red Sea by Mehanna and Abdallah where $E=0.80$, and the eastern side of Suez Gulf by El-Ganainy and Ahmed [15] where $\mathrm{E}=0.55$. It can be concluded that the $S$. rivulatus stock in the Egyptian Bitter Lakes is in a circumstances of overexploitation and to maintain 
this valuable fisheries resource some management measures, including reduction of the present level of fishing mortality and increase in the length at first capture should be applied.

\section{References}

1. Woodland DJ (1983) Zoogeography of the Siganidae (Pisces): an interpretation of distribution and richness patterns. Bulletin of marine science 33: 713-717.

2. Ben-Tuvia A (1985) The impact of the Lessepsian (Suez Canal) fish migration on the eastern Mediterranean ecosystem. In Mediterranean Marine Ecosystem (Moraitou-Apostolopoulou, M. and Kiortsis, V., eds): 367-375.

3. Papaconstantinou C (1990) The spreading of Lessepsian fish migrants into the Aegean Sea (Greece). Scientia marina 54: 313-316.

4. Bariche M, Letourneur $Y$, Harmelin-Vivien M (2004) Temporal fluctuations and settlement patterns of native and Lessepsian herbivorous fishes on the Lebanese coast (eastern Mediterranean). Environmental Biology of Fishes 70: 81-90

5. Azzurro E, Andaloro F (2004) A new settled population of the Lessepsian migrant Siganus luridus (Pisces: Siganidae) in Linosa Island, Sicily Strait. Journal of the Marine Biological Association United Kingdom 84: 819-821.

6. Shakman E, Boedeker C, Bariche M, Kinzelbach R (2009) Food and feeding habits of the Lessepsian migrants Siganus luridus Rüppell, 1828 and Siganus rivulatus Forsska ${ }^{\circ}, 1775$ (Teleostei: Siganidae) in the southern Mediterranean (Libyan coast). Journal of Biological Research-Thessaloniki 12: 115-124.

7. Crompton DWT (1985) Reproduction. In Biology of the Acanthocephala: 213-271.

8. Papoutsoglou SE, Papaparaskeva Papoutsoglou EG (1978) Comparative studies on body composition of rainbow trout (Salmo gairdneri R) in relation to type of diet and growth rate. Aquaculture 13: 235-243.

9. Hashem MT (1983) Biological studies on Siganus rivulatus (Forsk.) in the Red Sea. J. Fac. Mar. Sci., Jeddah 3: 119-127.

10. Ben-Tuvia A (1978) Immigration of fishes through the Suez Canal. Fish Bull 76: $249-255$

11. Abdel-Maguid SA (1997) Biological and hematological studies on marine coastal fishes, family. Gobiidae in Alexandria (Egypt). Ph.D. Thesis, Fac. Sci. Alex. Univ.

12. Philips AE, Akel EH (2003) Investigation of beach seine catches of Abu-Qir Bay (Egypt). Bull. Nat. Inst. Oceanogr. And Fish A R E 1: 79-91.

13. El-Gammal FI (1988) Age, growth and mortality of the rabbitfish Siganus rivulatus (Forssk.1775) from the Red Sea. Bull. Inst. Oceanogr. Fish. Egypt, 74: 13-21.

14. Shiekh-eldin MY (1988) Biological studies on certain marine teleosts. M. Sc. Faculty of Science, Ain Shams Univ.

15. El-Ganainy AA and Ahmed Al (2002) Growth, mortality and yield-per-recruit of the rabbit fish, siganus rjvula tus, from the eastern side of the Gulf of Suez, sinai coast, red se. Egypt J Aquai Biol Fisk 6: 67-81.

16. Hussein KA (1986) Timing of Spawning and Fecundity of Mediterranean Siganus rivulatus Forsskal. Bull. Inst. Oceanogr. Fish. Cairo vol 12: 175-186.

17. Mohamed NI (1991) Biological and Biochemical Studies of Some Siganid Fishes from the Mediterranean Waters off Alexandria, M.Sc. Thesis, Fac. Sci., Alexandria University.

18. Taskavak E, Bilecenoglu M (2001) Length-weight relationship for 18 Lessepsian (Red Sea) immigrant fish species from the eastern Mediterranean coast of Turkey. J Mar Biol Assoc U K 18: 895-896.

19. Bariche M (2005) Age and growth of Lessepsian rabbitfish from the eastern Mediterranean. Journal of Applied Ichthyology 21: 141-151.

20. Amin EM (1985) Reproductive cycle of male Siganus rivulatus Forsskal with indication to Gonosomatic and Hepatosomatic Indices. Bull. Inst. Oceanogr. Fish. Cairo 11: 149-164.

21. Lundberg B, Lipkin $Y$ (1992) Seasonal, grazing site and fish size effects on patterns of algal consumption by the herbivorous fish, Siganus rivulatus, At Mikhmoret (Mediterranean, Israel). Environm. Quality, Ecosy. Stability, Vol. V/B.

22. Lundberg B, Golani D (1995) Diet adaptations of Lessepsian migrant rabbitfish, Siganus luridus and $\mathrm{S}$. rivulatus, to the algal resources of the Mediterranean Coast of Israel. Mar Ecol - P.S.Z.N.I 16: 73-89.
23. El-Okda NI (1998) Comparative studies on certain biological aspects of Siganus in marine waters of Egypt. Ph. D. Thesis, Fac. Sci., (Benha) Zagazig. Univ.

24. Yeldan H, Avşar D (2000) A preliminary study on the reproduction of rabbit fish Siganus rivulatus (Forsskål, 1775), in the northeastern Mediterranean. Turk $J$ Zool 24: 173-182.

25. Shakman E, Winkler H, Oeberst R, Kinzelbach R (2008) Morphometry, age and growth of Siganus luridus Rüppell, 1828 and Siganus rivulatus Forsskål, 1775 (Siganidae) in the central Mediterranean (Libyan coast). Revista de Biología Marina y Oceanografía 43: 521-529.

26. Tacon AG, Rausin N, Kandari M, Cornelis P (1990) The food and feeding of marine fin fish in floating net cages at the National Sea Farming Development Centre, Lampung, Indonesia: Rabbitfish Siganus canaliculatus (Park), Aquaculture and Fish. Management 21: 375-339.

27. Carumbana EE, Luchavez JA (1979) A comparative study of the growth rates of Siganus canaliculatus, S. spinus and S. guttatus reared under laboratory and semi-natural conditions in Southern Negros Oriental, Philippines. Silliman Journal 26: 187-209

28. Beckman DW, Wilson CA (1995) Seasonal timing of opaque zone formation in fish otoliths. In: Recent developments in fish otolith research. D. H. Secor; J. M. Dean and S. E. Campana (Eds). University of South Carolina Press, Columbia.

29. Sparre P, Venema SC (1992) Introducion to tropical fish stock assessment Part I: Manual. FAO Fisheries Technical Paper No. 306.

30. Von Bertalanffy L (1938) A quantitative theory of organic growth. Human Biology 10: 181-213.

31. Ricker WE (1973) Linear regressions in fishery research. Journal of the Fisheries Research Board of Canada 30: 409-434

32. Ricker WE (1975) Computation and interpretation of biological statistics of fish populations. Bulletin of the Fisheries Research Board of Canada 191: 1-382.

33. Beverton RJ, Holt SJ (1957) On the dynamics of exploited fish populations. U. K. Min. Agric Fish Fish Invest 19: 230-233.

34. Sparre P, Ursin E, Venema SC (1989) Introduction to tropical fish stock assessment. Part 1. Manual. FAO Fisheries Technical Paper No: 306.

35. Pauly D (1983) Length-converted catch curves. A powerful tool for fisheries research in -tropics. Parti. ICLARM Fishbyte 2: 17-19.

36. Gulland JA (1971) The fish resources of the Ocean. West Byfleet, Surrey, Fishing News (Books), Ltd., for FAO: $255 \mathrm{p}$.

37. Brothers EB (1979) Age and growth studies on tropical fishes. In Stock Assessment for Tropical Small-Scale Fisheries (B. S. Saila and P.M. Roedel, eds), pp. 119-1 36. Rhode Island: International Center for Marine Resource Development, University of Rhode Island.

38. Golani D, Ben-Tuvia A (1985) The biology of the Indo-Pacific squirrelfish, Sargocentron rubrum (Forsska ${ }^{\circ}$ ), a Suez Canal migrant to the eastern Mediterranean. J Fish Biol 27: 249-258.

39. Mehanna SF, Abdallah M (2002) Population dynamic of the rabbitfish, Siganus rivulatus, from the Egyptian sector of the Red Sea. J K A U Mar Sci 13: 1-170.

40. Yeldan H, Avşar D (2000) A preliminary study on the reproduction of rabbit fish, Siganus rivulatus (Forsskăl, 1775), in the northeastern Mediterranean. Turk Zool 24: 173-182.

41. Akşiray F (1987) Türkiye Deniz Baliklari ve Tayin Anahtari (The identification sheets for the Turkey's marine fishes). Istanbul Üniv.Rektorüğü lyayinlari. No: 3490. II: Baski.811p

42. Golani D (1990) Environmentally-induced meristic change in Lessepsian fish migrants, a comparison of source and colonizing populations. Bulletin de I'Institut Océanographique de Monaco 7: 143-152.

43. Bariche ML, Harmelin MV, Quignard JP (2003) Reproductive cycle and spawning periods of two Lessepsian siganid fishes on the Lebanese coast. $J$ Fish Biol 62: 129-142.

44. Torcu H (1994) Indo Pacific-fish species distributed along Southern Aegean Sea and Mediterranean, and the studies on the biology and ecology of gatfish (Upeneus moluccensis, Bleeker, 1885) and Lizardfish (Saurida undosquamis Richardson, 1848). Selçuk Üniversitesi Fen Bil. Enst. Doktora Tezi. Koya.124p.

45. Popper DM, Gordin H, Kissil GW (1973) Fertilization and hatching of rabbitfish Siganus rivulatus.Aquaculture 2: $37-44$ 